\title{
Tudi stari Slovani so poznali gnomone
}

\begin{abstract}
Andrej Pleterski
Prepričanje, da so za naše poznavanje preteklih znanj merodajni samo zapisi starogrške znanosti in da zunaj teh znanj ni ničesar, česar ni v pisnih virih, je zavajajoče. Stari Slovani so svoje znanje matematike in astronomije lahko razvili neodvisno od starogrške znanosti. Zaničevanje znanja starih Slovanov ob njegovem primerjanju s starogrškim je $v$ izhodišču zgrešeno in ne more privesti do uporabnih ugotovitev.
\end{abstract}

KLJUČNE BESEDE: stari Slovani, stari Grki, arheoastronomija
The belief that only written records of ancient Greek science are relevant to our knowledge of past science and that there is nothing outside of that knowledge that is not contained in written sources is misleading. The ancient Slavs were able to develop their knowledge of mathematics and astronomy independently of ancient Greek science. Neglecting the knowledge of the ancient Slavs in comparing it with that of the ancient Greeks is misguided and cannot lead to useful findings.

KEYWORDS: ancient Slavs, ancient Greeks, archeoastronomy

V pokrajini obstajajo matematične in astronomske pravilnosti. Zakaj je temu tako, je predmet številnih znanstvenih razprav. V teh razpravah so možni različni pogledi in posledično različni zaključki. Moje raziskave kažejo, da so te pravilnosti posledica fenomena, ki ga imenujem mitična pokrajina (Pleterski 2018) in ga pojasnjujem prvenstveno na primeru starih Slovanov. Ena od mnogih pravilnosti je ponavljanje kota $23,5^{\circ}$, ki ni naključno in ga najbolj smiselno pojasnjuje nagnjenost ekliptike. Tomislav Bilić je mitično pokrajino zreduciral na trikotnik s kotom $23,5^{\circ}$ in poskušal dokazati, da ga stari Slovani niso mogli poznati ter ga razglaša za mit o »sončnem kotu« starih Slovanov (Bilić 2020). Čeprav se ne strinjava, mu moram najprej izreči priznanje, da je našel voljo in čas ter svojo kritiko tudi napisal. ${ }^{1} \mathrm{~S}$ tem je dal pomemben pospešek diskusiji o mitični pokrajini.

Pravilno je opazil, da sem pred četrt stoletja pri svoji prvi predstavitvi ideje, od kod ponavljanje kota $23^{\circ}$ med kulturno in simbolno pomembnimi točkami v pokrajini, zagrešil lapsus pri definiciji nagnjenosti ekliptike (Pleterski 1996: 182). S tem sem nehote povzročil ponavljanje in celo nadaljnjo erozijo te napačne definicije pri vrsti kolegov na Hrvaškem, ki se jim na tem mestu opravičujem za slab zgled. Pri opozarjanju na te

1 Op. ur.: Bilićev prispevek in kritika je objavljena v Studii Mythologici Slavici 23 (2020), 35-50. 
napačne definicije se Bilić ne moti. Ne drži pa njegova trditev, da tega lapsusa nisem opazil dve desetletji in da $\mathrm{v}$ treh publikacijah uporabljam hkrati pravilno in napačno definicijo. Kdaj sem opazil spodrsljaj, se res ne spominjam več. Ga pa že v objavi iz leta 2002 ni več. Vendar v nasprotju z Bilićevim pričakovanjem kota tam ne definiram s presekom dveh ravnin, ampak z odklonom osi Zemljinega vrtenja od pravokotnice na ravnino Zemljine krožnice okoli Sonca. V navedenem delu res stilistično slabo povem, da os Zemljinega vrtenja ni pravokotna na ravnino njene orbite okoli Sonca, ampak gre za omenjeni kot odklonjena (Pleterski, Belak 2002: 19, 49). In stilistična slabost je, da ne poudarim odklona od pravokotnice na ravnino orbite. Ta kot kaže tudi Bilićeva slika 1, zato se mi je ta pravokotnica zdela samoumevno zaobsežena v navedbi, da os Zemljinega vrtenja ni pravokotna na Zemljino orbito. Vse nadaljnje definicije so zato pravilne; dvojnost, ki jo je Bilić opazil, pa je v tem, da lahko ta kot definiramo na dva načina, z dvema ravninama ali pa s pravokotnicama na ti dve ravnini, kar kaže tudi Bilićeva slika $1 \mathrm{z}$ dvakratno oznako $\varepsilon$.

Za tokratno razpravo o zapisu matematike in astronomije v pokrajino je seveda pomembno vprašanje, kaj današnje poznavanje definicije nagnjenosti ekliptike pomeni za ta zapis v preteklosti. Trdim, da nič. Pri vsem tem je namreč najpomembnejše dejstvo, da je sonce pri nas poleti višje na nebu kot pozimi in da to ni prav nič odvisno od tega, kako ta pojav definiramo. Definicija nam samo pomaga razumeti pojav, vendar ga sama ne povzroča. Tako je bilo s soncem, še preden so se pojavili ljudje, in tako bo, ko ljudi ne bo več.

Živimo v obdobju informatike. Število objav v odprtem dostopu se veča vsako sekundo in z lahkoto moremo zbrati citate za kakršnokoli trditev, vendar pa število citatov $\mathrm{k}$ neki trditvi ni nikakršno potrdilo za njeno pravilnost. Citat je zgolj orodje za preverjanje trditev. Zato se osebno pri citatih držim načela, manj je več.

Če želim v nadaljevanju razumljivo pokazati, da je Bilićeva kritika povsem zgrešena, moram najprej opozoriti na nekatere njegove tihe teoretične predpostavke (zapisujem jih krepko), o katerih pa lahko sklepam iz načina njegovega argumentiranja, ki je izrazito deduktivno in v zvezi s starimi Slovani zanemarja empirijo.

Današnje astronomsko znanje je izhodišče za ocenjevanje astronomskega znanja v preteklosti. - Bilić poudarja starogrško tradicijo kot izvor sodobne astronomije in kot odločilno postavlja vprašanje, kako se domnevno poznavanje razmeroma točne mere naklona ekliptike pri starih Slovanih vklaplja v znanje moderne zgodovine znanosti o razvoju primerljivih znanj v grški tradiciji. Nato prikaže starogrško znanje o naklonu ekliptike in v nadaljevanju še starogrško prepoznavanje in razlage solsticijev, kot izpričujejo pisni viri.

Staroslovanski žreci bi morali poznati dela Eratostena ali Hiparha, da bi zmogli v pokrajini postaviti trikotnik s kotom $23,5^{\circ}$ ali pa sami na enak način kot starogrški modreci izračunati ta kot in zapustiti v pisnih virih sledove tega miselnega procesa. - Iz tega Bilić izpelje trditev, da ni dokaza (samega obstoja trikotnikov s tem kotom ne priznava za dokaz), da bi Slovani poznali mero naklona ekliptike, bodisi da bi do nje prišli neodvisno ali pa bi jo prevzeli iz grške znanosti.

Trdnost Bilićevega sklepanja je samo navidezna. Kot $23,5^{\circ}$ lahko postavimo v prostor, tudi če nimamo nobenega znanja o merah naklona ekliptike. Določimo ga lahko geometrijsko, če imamo postavljen gnomon in celo leto opazujemo gibanje njegove sence. 


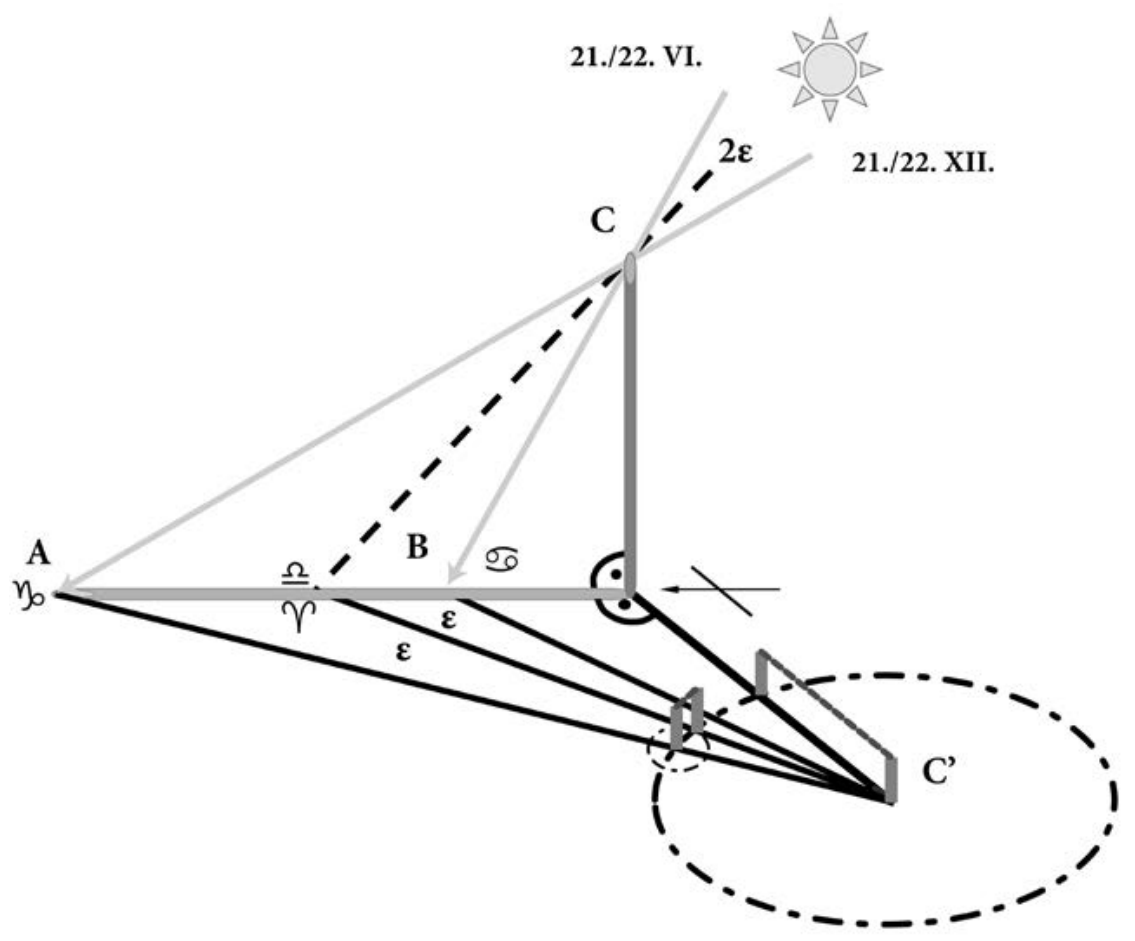

Slika 1. Uporaba gnomona pri določanju in prenašanju kota $23,5^{\circ}$.

S pomočjo štirih količkov in dveh vrvic ga lahko nato kadarkoli prenesemo kamorkoli in v katerokoli smer (Slika 1). Starim Slovanom ni bilo treba poznati niti Eratostena niti Hiparha niti izračunavati kota. In zakaj bi ga hoteli postaviti? Povezava med višino sonca in letnimi časi je očitna. Postavitev kota $23,5^{\circ}$ po načelih imitativne magije zagotavlja naravno ravnovesje in pravilen tek letnih časov.

Res je na možnost opazovanja sence gnomona pomislil tudi Bilić, a jo je zavrnil s trditvijo, da uporaba gnomona pri starih Slovanih ni poznana. Še več, trdi, da ni nobenega dokaza za obstoj kateregakoli astronomskega pojma ali postopka v njihovem znanju. Kateregakoli raziskovalca starih Slovanov zanesljivo ne bo prepričal o resničnosti teh svojih trditev.

Res je, da o znanju starih Slovanov pisni viri ne dajejo uporabnih podatkov in so v tem pogledu stari Slovani nevidni. Vendar naj spomnim, da arheologija zmore predstavljati preteklost s pomočjo tvarnih virov. Velika večina arheologov, ki raziskuje prostor, se vsaj od Binforda dalje strinja, da je pokrajina tvarni vir (artefakt). Vanjo so ljudje zapisovali tudi svoje misli s pomočjo ideogramov. Jaz jo imenujem mitična pokrajina in kot 23,5 je samo ena od njenih številnih sestavin. Kako kompleksen fenomen je mitična pokrajina, prikazujem v svoji monografiji „Kulturni genom“(Pleterski 2014). V mitični pokrajini se prepletajo informacije arheologije, arheoastronomije, jezikoslovja, folkloristike, pisnih virov. V njej so matematične, astronomske in folkloristične strukture, ki se ponavljajo. 
Vse to je bilo mogoče opaziti empirično, številne primere podrobno opisujem v knjigi Kulturni genom (2014). Ta knjiga predstavlja induktivni del raziskovalnega postopka, ki je omogočil postavitev teoretičnega modela in preverljive hipoteze. Ta je bila potrjena $\mathrm{z}$ arheološkimi izkopavanji v Bodeščah (Pleterski 2020; Modrijan 2020), kar je deduktivni del raziskovalnega postopka o mitični pokrajini.

Za konec še nekaj konkretnosti. Že leta 2003 sva z Jiřijem Marešom pokazala način, kako so stari Slovani lahko uporabljali gnomon, prikaz obsega tudi prenos kota v vodoravno ravnino (Pleterski, Mareš 2003, Abb. 2). Prav tako tam predstaviva dva ohranjena gnomona in sledove drugih dveh pri starih Slovanih (Pleterski, Mareš 2003: 18-24). V knjigi Kulturni genom (2014) dodatno prikazujem sledove dveh gnomonov (Pleterski 2014: 205-207, 211) in temu v svoji zadnji objavi dodajam še štiri (Pleterski 2020: 267-271); nadaljnje kopičenje se mi ne zdi potrebno.

\section{LITERATURA}

Modrijan, Zvezda, 2020: Bodešče. Srednjeveški Blejski otok v arheoloških virih. $=$ Medieval archaeology of Bled Island (ur. Štular, Benjamin). Ljubljana: Opera Instituti archaeologici Sloveniae 42. 279-286.

Pleterski, Andrej, 1996: Strukture tridelne ideologije v prostoru pri Slovanih. Zgodovinski časopis $50,163-185$.

Pleterski, Andrej, 2014: Kulturni genom. Prostor in njegovi ideogrami mitične zgodbe. Ljubljana: Studia mythologica Slavica, Supplementa, suppl. 10.

Pleterski, Andrej, 2018, Mythical landscape: what is it?. Sacralization of landscape and sacred places: proceedings of the 3rd International Conference of Mediaeval Archaeology of the Institute of Archaeology, Zagreb, 2nd and 3rd June 2016, (ur. Belaj, Juraj; Zbornik Instituta za arheologiju, knj. 10, vol. 10). Zagreb, 5-18.

Pleterski, Andrej, 2020: Mitična pokrajina. Preizkusi njenega obstoja z napovednima modeloma na primeru Bleda. $=$ A mythical landscape. Tests of its existence with predictive models for the Bled case. Srednjeveški Blejski otok v arheoloških virih. = Medieval archaeology of Bled Island (ur. Štular, Benjamin). Ljubljana: Opera Instituti archaeologici Sloveniae 42. 235-277.

Pleterski, Andrej in Mateja Belak, 2002: Grobovi s Puščave nad Starim trgom pri Slovenj Gradcu. Arheološki vestnik 53, 233-300.

Pleterski, Andrej in Jiř́ J. MAREŠ, 2003: Astronomische Grundlagen einiger frühmittelalterlichen Kultstellen in Praha. Studia mythologica Slavica 6, 9-35. 


\section{The ancient Slavs also knew gnomons}

\section{Andrej Pleterski}

There are mathematical and astronomical regularities in the landscape, and the reasons for their existence are the subject of much scientific discussion. Indeed, different views are possible and, consequently, varied conclusions can be drawn. My research shows that these regularities result from a phenomenon that I call a mythical landscape (Pleterski 2018), which I explain primarily in reference to the ancient Slavs. One of many regularities is the repetition of the angle of $23.5^{\circ}$, which is not random and is most sensibly explained by the obliquity of the ecliptic. Tomislav Bilić has reduced the mythical landscape to a triangle with an angle of $23.5^{\circ}$, trying to prove that the ancient Slavs could not have known it, proclaiming it the myth of the "solar angle" of the ancient Slavs (Bilić 2020). ${ }^{1}$ Although we disagree, I must first acknowledge his personal determination to find the will and the time to write a critique. In doing so, he has given significant impetus to the discussion regarding the mythical landscape.

Bilić has rightly observed that, a quarter of a century ago, in my first presentation of the notion of the repetition of the $23^{\circ}$ angle between culturally and symbolically significant points in the landscape, I made lapsus in defining the obliquity of the ecliptic (Pleterski 1996: 182). With this, I unintentionally caused a recurrence and even further erosion of this misconception with some colleagues in Croatia, to whom I now apologise for setting a bad example. Bilić is not mistaken in highlighting these erroneous definitions. However, his claim that I did not notice this lapse in the previous two decades and that I have used correct and incorrect definitions in three publications simultaneously is not true. I no longer remember when I first recognised the error, but it was certainly not apparent in the 2002 publication.

Nevertheless, contrary to Bilić's expectation, the angle there is not defined by the intersection of two planes but by the deviation of the axis of the Earth's rotation from a rectangle to the Earth's orbital plane. I said this stylistically badly: I simply stated that the axis of the Earth's rotation is not perpendicular to the plane of its orbit around the Sun, but rather is deflected by said angle (Pleterski, Belak 2002: 19, 49). Moreover, the stylistic weakness is not to point out that the axis of the Earth's rotation is deflected from a rectangle to the plane of the orbit. This angle is also shown in Bilić's Figure 1, and the rectangle seemed to me to have been taken for granted in the statement that the axis of the Earth's rotation is not perpendicular to the Earth's orbit. Therefore, all further definitions are correct, but the duality that Bilić observed is that the discussed angle can be defined

1 Editorial comment: The article and critic from T. Bilić was published in Studia Mythologica Slavica 23 (2020), 35-50. 
in two ways: either with two planes or with rectangles on both, as additionally shown in Bilić's Figure 1 with the double notation of $\varepsilon$.

Of course, for the present discussion of the mathematical and astronomical record in the landscape, the important question pertains to what contemporary knowledge regarding a definition of the obliquity of the ecliptic means to this record in the past. I claim nothing. The most important point is that in the summer, the Sun is higher in the sky than in the winter and that this does not depend on how we define this phenomenon: the definition helps us understand the phenomenon, but it does not cause it. This fact was true even before humans appeared and will remain so after we are gone.

We live in the age of information technology. The number of open access publications is increasing every second, and we can easily collect quotations for any claim. Their number depends only on how long we choose to sit at the computer. The number of quotations to a claim does not in any way confirm its correctness. A quotation is merely a tool for verifying claims. That is why when quoting, I personally adhere to the principle of less is more.

To make clear below that Bilić's critique is totally mistaken, I must first highlight some of his quiet theoretical assumptions (I write these in bold), of which he may not even be aware, but which I can conclude from his method of argument, which is distinctly deductive and neglects empiricism in relation to the ancient Slavs.

Today's astronomical knowledge is the starting point for evaluating astronomical knowledge in the past. Bilić emphasises the ancient Greek tradition as the origin of modern astronomy, and as a decisive question, how the supposed knowledge of the ancient Slavs - of the relatively accurate value of the obliquity - fits into the knowledge of the modern history of the science that speaks of the development of comparable knowledge in the Greek tradition. He then presents ancient Greek knowledge of the value of the obliquity and the ancient Greek understanding of the annual solar movement with the solstices, as written sources testify.

Ancient Slavic priests should be familiar with the works of Eratosthenes or Hipparchus in order to be able to set up a triangle at an angle of $23.5^{\circ}$ in the landscape, or to calculate this angle in the same way as the ancient Greek sages did and to leave traces of this thought process in written sources. From this, Bilić derives the claim that there is no proof (he does not admit the very existence of triangles with this angle as evidence) that the Slavs knew the value of the obliquity, either to calculate it independently or to assume it from Greek science.

The tenacity of Bilić's reasoning is only apparent. An angle of $23.5^{\circ}$ can be placed in the landscape even if we have no knowledge of the value of the obliquity of the ecliptic. It can be determined geometrically if we have a gnomon in place and we observe the movement of its shadow all year long. With the help of four sticks and two ropes, the angle can then be transferred at any time in any direction (Figure 1). The ancient Slavs did not need to know Eratosthenes, Hipparchus, or how to calculate angles. Furthermore, why would they want to put the angle in landscape? The connection between the height of the Sun and the seasons is obvious. Setting an angle of $23.5^{\circ}$ according to the principles of imitative magic ensures a natural balance of the seasons' proper course. 


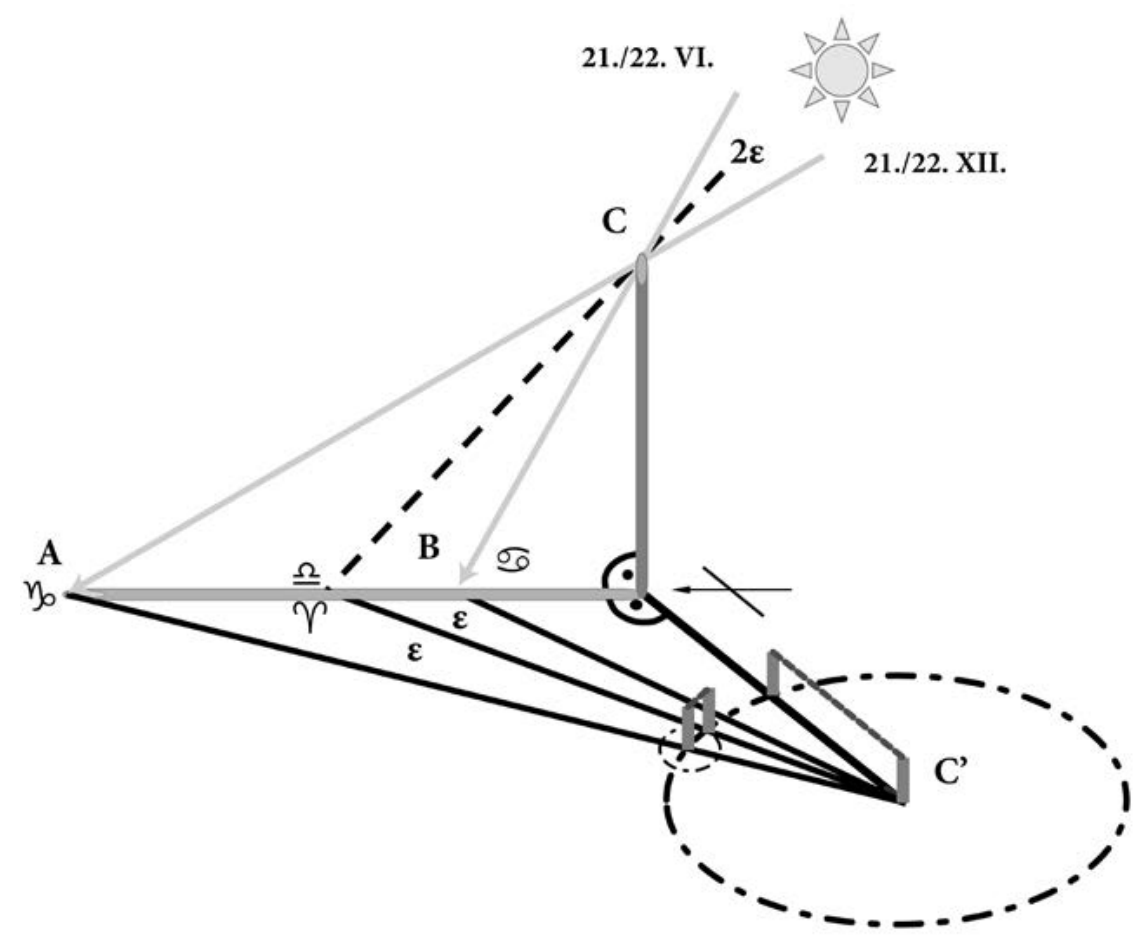

Figure 1. Use of gnomon in determining and passing the angle of $23.5^{\circ}$.

True, the possibility of observing the gnomon's shadow is also considered by Bilić, but he rejects it by claiming that the use of the gnomon was not known to the ancient Slavs. Moreover, he argues that there is no evidence for the existence of any astronomical concept or process in their knowledge. Any researcher of the ancient Slavs will certainly be uncertain of the value of his claims.

It is true that written sources do not provide useful information about the knowledge of the ancient Slavs and they are invisible in this respect. However, let me remind the reader that archaeology can represent the past through material sources. The vast majority of archaeologists exploring the landscape agree, at least from Binford onwards, that the landscape is a material source (an artefact). People would also write down in the landscape their thoughts using ideograms. I term this the "mythical landscape", with the angle of $23.5^{\circ}$ as just one of its many components. I demonstrate the complexity of the mythical landscape as a phenomenon in my monograph The Cultural Genome (Pleterski 2014). In the mythical landscape, information about archaeology, archaeoastronomy, linguistics, folklore studies, and written sources intertwine. It contains repeated mathematical, astronomical, and folkloristic structures. All of this could be observed empirically, and I describe many examples in detail in my monograph. This book represents the inductive part of the research process. It made it possible to establish a theoretical model and a verifiable hypothesis, which was confirmed by archaeological excavations in Bodešče 
(Pleterski 2020; Modrijan 2020), a deductive part of the research process on the mythical landscape.

Finally: some concreteness. As early as 2003, Jiří Mareš and I showed how the ancient Slavs were able to use the gnomon, involving the transfer of the angle to the horizontal plane (Pleterski, Mareš 2003, Abb. 2). We also represented two preserved gnomons and traces of the other two in the ancient Slavs (Pleterski, Mareš 2003: 18-24). In The Cultural Genome, I additionally show traces of two gnomons (Pleterski 2014: 205-207, 211), while in my most recent publication I add four more gnomons (Pleterski 2020: 267-271). No further accumulation of gnomons seems necessary.

\section{BIBLIOGRAPHY}

Modrijan, Zvezda, 2020: Bodešče. Srednjeveški Blejski otokv arheoloških virih. $=$ Medieval archaeology of Bled Island (ed. Štular, Benjamin). Ljubljana: Opera Instituti archaeologici Sloveniae 42. 279-286.

Pleterski, Andrej, 1996: Strukture tridelne ideologije v prostoru pri Slovanih. Zgodovinski časopis $50,163-185$.

Pleterski, Andrej, 2014: Kulturni genom. Prostor in njegovi ideogrami mitične zgodbe. Ljubljana: Studia mythologica Slavica, Supplementa, suppl. 10.

Pleterski, Andrej, 2018, Mythical landscape: what is it?. Sacralization of landscape and sacred places: proceedings of the 3rd International Conference of Mediaeval Archaeology of the Institute of Archaeology, Zagreb, 2nd and 3rd June 2016, (ed. Belaj, Juraj; Zbornik Instituta za arheologiju, knj. 10, vol. 10). Zagreb, 5-18.

Pleterski, Andrej, 2020: Mitična pokrajina. Preizkusi njenega obstoja z napovednima modeloma na primeru Bleda. $=$ A mythical landscape . Tests of its existence with predictive models for the Bled case. Srednjeveški Blejski otok v arheoloških virih. $=$ Medieval archaeology of Bled Island (ed. Štular, Benjamin). Ljubljana: Opera Instituti archaeologici Sloveniae 42. 235-277.

Pleterski, Andrej in Mateja Belak, 2002: Grobovi s Puščave nad Starim trgom pri Slovenj Gradcu. Arheološki vestnik 53, 233-300.

Pleterski, Andrej in Jiř́ J. MAREŠ, 2003: Astronomische Grundlagen einiger frühmittelalterlichen Kultstellen in Praha. Studia mythologica Slavica 6, 9-35.

Andrej Pleterski, red. prof. dddr., upokojeni sodelavec ZRC SAZU, Novi $\operatorname{trg} 2$, SI - 1000 Ljubljana, Slovenija, andrej.pleterski@zrc-sazu.si 